\title{
ANALISIS POTENSI ENERGI TERBARUKAN PEMBANGKIT LISTRIK TENAGA MIKROHIDRO DI MANOKWARI SELATAN
}

\section{(THE ANALYSIS OF RENEWABLE ENERGY POTENTIAL OF MICROHYDRO POWER PLANT IN SOUTH MANOKWARI)}

\author{
Elias K. Bawan ${ }^{1}$, Antonius D. Palintin ${ }^{1}$, dan Eric A. Patandianan ${ }^{2}$ \\ ${ }^{1}$ Fakultas Teknik Universitas Papua Indonesia \\ ${ }^{2}$ Fakultas Teknik Pertambangan dan Perminyakan Universitas Papua Indonesia \\ Jalan Gunung Salju Amban Manokwari Papua Barat \\ email: e.bawan@unipa.ac.id
}

\begin{abstract}
Abstrak
Tujuan dari penelitian ini adalah menganalisis potensi energi listrik di kabupaten Manokwari Selatan. Penelitian dilaksanakan pada bulan Juli 2019 di Kabupaten Manokwari Selatan pada tiga Distrik. Survei geologi dilakukan dengan pendekatan geologi regional Lembar Ransiki. Untuk analisis hidrologi dan kemiringan lereng dilakukan dengan menggunakan citra satelit, Digital Elevation Model (DEM) dan Peta Rupa Bumi Indonesia (RBI) dan aplikasi Sistem Informasi Geografis (SIG) serta pengukuran di lapangan untuk penentuan debit lapangan. Kondisi hidrologi yang menjadi kajian meliputi potensi debit dan curah hujan. Perhitungan debit air pada DAS menggunakan metode FJ. Mock. Data evapotranspirasi potensial dihitung dengan menggunakan metode Pennman Modifikasi. Penelitian ini menunjukkan bahwa debit andalan pada sungai Susmorof mencapai $1500 \mathrm{~L} / \mathrm{dt}$ masing-masing untuk kepentingan pengembangan sistem. Total potensi PLTMH di dua lokasi yang dikaji adalah sebesar 30,4 kW di sungai Bengko kampung Sihu dan 73,4 kW. Untuk pengembangan PLTMH di Kampung Susmorof hal ini penting untuk ditindaklanjuti pada tahapan studi kelayakan dan penyusunan perencanaan detail desain.

Kata kunci: pembangkit listrik tenaga mikrohidro, FJ Mock, metode Pennman, Manokwari Selatan
\end{abstract}

\begin{abstract}
The purpose of this study was to analyze the potency of electrical energy in South Manokwari district. The research was conducted in July 2019 in South Manokwari Regency in three districts. The geological survey was carried out using the Ransiki Sheet regional geological approach. For hydrological and slope analysis, satellite imagery, Digital Elevation Model (DEM) and Indonesian Earth Map (RBI) and Geographic Information System (GIS) applications as well as measurements in the field were used to determine field discharge. The hydrological conditions under study include the potential for discharge and rainfall. Calculation of water discharge in the watershed uses the FJ Mock method. Potential evapotranspiration data were calculated using the Modified Pennman method. This study shows that the mainstay discharge in the Susmorof river reaches $1500 \mathrm{~L} / \mathrm{s}$ each for the purpose of system development. The total potential for MHP in the two locations studied are $30.4 \mathrm{~kW}$ in the Bengko river, Sihu village and $73.4 \mathrm{~kW}$. For the development of MHP in Susmorof Village, this is important to be followed up at the stage of feasibility studies and preparation of detailed design planning.
\end{abstract}

Keyword: Micro hydro power plant, FJ Mock, Pennman method, South Manokwari 
Analisis Potensi Energi Terbarukan (Bawan, E. K., Palintin, A. D., \& Patandianan, E. A.)

\section{PENDAHULUAN}

Indonesia merupakan salah satu negara kepulauan terbesar di dunia dengan luas 8,3 juta $\mathrm{km}^{2}$, sekitar $77 \%$ merupakan permukaan air dan sebanyak 17.504 pulau. Sekitar 111 di antaranya berada di pulau terluar yang berbatasan langsung dengan negara-negara lain (Reinders, 2020).

Di daerah yang memiliki jumlah industri yang besar memiliki akses tenaga listrik yang sangat bagus termasuk di daerah Jawa dan beberapa daerah lainnya sedangkan di daerah lain termasuk bagian Timur Indonesia memiliki akses yang cukup rendah. Kementerian Energi dan Sumber Daya Mineral (ESDM) menyatakan asumsi dasar makro sektor energi dan sumber daya mineral dalam rancangan RAPBN 2020 menyebutkan rasio elektrifikasi pada tahun 2020 mencapai 99,99\% (Agustus 2019). Paparan ESDM hingga 2018 masih terdapat $1,7 \%$ wilayah yang belum teraliri listrik dan pada Juli 2019 mencapai 98,2\% dan daerah yang terendah adalah Papua dan NTT. Jaringan listrik di Indonesia baru menjangkau $85 \%$ dari 82.190 desa. Sebanyak 2.519 desa bahkan belum merasakan layanan listrik sama sesungai, 2.376 di antaranya ada di pulau Papua. Sisanya belum mendapat layanan secara penuh dalam 24 jam menurut data ESDM (Kementerian ESDM, 2016).

Masyarakat yang tinggal di pulaupulau kecil atau daerah pedesaan, di mana jaringan distribusi tenaga listrik tidak ada atau secara teknis dan ekonomi sangat sulit untuk membangun jaringan transmisi dan distribusi tenaga listrik (Tan et al.,2014). Membangun pembangkit tenaga listrik di daerah terpencil membutuhkan biaya yang besar dan kesulitan yang tinggi. Oleh karena itu, pada beberapa tahun sebelumnya, pembangkit listrik yang paling poluler bagi daerah kepulauan dan pedesaan adalah generator disel, selain oleh karena instalasi yang sederhana tetapi juga biaya investasi awal yang rendah (Galvez, 2015).

Sistem kelistrikan di Provinsi Papua Barat masih terisolasi. Meskipun relatif kaya dengan sumber daya energi (baik fosil maupun nonfosil) yang dimanfaatkan untuk kelistrikan. Permintaan listrik terus meningkat namun tidak sebanding dengan kemampuan kapasitas pembangkit yang telah ada. Percepatan pembangunan pembangkit energi terbarukan segera dilaksanakan seperti air, angin dan tenaga matahari) untuk memenuhi permintaan secara total dan disisi lain meminimalkan kebiasaan mengandalkan listrik berbahan bakar minyak seperti PLTD (Oktaviani, 2016).

Potensi energi air di Papua Barat cukup besar, beberapa di antaranya adalah di Kabupaten Pegunungan Arfak antara lain Pasalli dan Rehiara (2014) telah melakukan studi perencanaan design PLTMH di sungai Hingk dengan potensi maksimal $25,2 \mathrm{~kW}$ 
dengan head 8,6 meter dan debit air $0,3 \mathrm{~m}^{3} /$ detik dan produksi energi listrik 17,32 kW. Potensi PLTMH beberapa sungai lainnya di pegunungan Arfak seperti sungai Indabri 26,4 kW, sungai Demaisi 22,1 kW, sungai Sururey 9,7 kW dan sungai Kopo 5,9 kW (Palintin, 2020). Potensi PLTMH di kampung Sasnek Distrik Sawiat Kabupaten Sorong Selatan Provinsi Papua Barat sebesar $10 \mathrm{~kW}$ dengan debit 2 liter/detik memanfaatkan debit $0,65 \mathrm{~m} 3 /$ detik dengan faktor koreksi 0,75 oleh karena kondisi air sungai mengalir sepanjang tahun (Tobi \& Van Harling, 2017).

Energi baru terbarukan (EBT) adalah sumber-sumber energi yang terus menerus dibaharui oleh alam dan berasal langsung dari matahari (seperti termal, foto-kimia, dan foto-listrik), secara tidak langsung dari matahari (seperti angin, tenaga air, dan energi fotosintesis yang tersimpan di biomassa), atau dari gerakan dan mekanisme alami lingkungan lainnya seperti energi panas bumi (Ellabban et al., 2014).

Pemanfaatan energi terbarukan menjadi solusi alternatif dan dapat dioptimalkan terutama di daerah yang belum mendapatkan akses jaringan distribusi tenaga listrik PLN seperti pedesaan, kepulauan dan pegunungan. Papua Barat memiliki potensi air yang cukup besar sehingga berpeluang untuk membangkitkan energi listrik dari tenaga air. Pembangkit listrik tenaga mikrohidro merupakan salah satu pembangkit listrik yang menggunakan tenaga air dengan kapasitas tidak lebih dari $100 \mathrm{~kW}$ yang bisa berasal dari saluran irigasi, sungai, atau terjun air alam dengan memanfaatkan tinggi terjunan (head) dan debit air.

Kabupaten Manokwari Selatan merupakan salah daerah pemekaran secara administratif dari kabupaten Manokwari pada bulan November 2012 selain kabupaten Pegunungan Arfak. Kabupaten Manokwari

Tabel 1

Distribusi Penduduk Menurut Distrik dan Luas Wilayah

\begin{tabular}{llccccc}
\hline No & Distrik & $\begin{array}{c}\text { Luas } \\
\text { Wilayah } \\
\left(\mathrm{Km}^{2}\right)\end{array}$ & $\begin{array}{c}\text { Jumlah } \\
\text { Penduduk } \\
\text { (ribu) }\end{array}$ & $\begin{array}{c}\text { Jumlah } \\
\text { Rumah } \\
\text { Tangga }\end{array}$ & $\begin{array}{c}\text { Kepadatan } \\
\text { Penduduk } \\
\left(\text { jiwa/Km }{ }^{2}\right)\end{array}$ & $\begin{array}{c}\text { Jumlah } \\
\text { Desa }\end{array}$ \\
\hline 1 & Tahota & 604,15 & 622 & 156 & 1,03 & 4 \\
2 & Dataran Isim & 862,86 & 2.203 & 583 & 2,55 & 12 \\
3 & Neney & 249,55 & 1.271 & 294 & 5,09 & 7 \\
4 & Momi Waren & 456,18 & 2.687 & 610 & 5,89 & 7 \\
5 & Ransiki & 273,24 & 10.184 & 2029 & 37,28 & 13 \\
6 & Oransbari & 366,46 & 6.650 & 1492 & 18,15 & 14 \\
\hline & Jumlah & 2812,44 & 23.617 & 5164 & 8,40 & 57 \\
\hline
\end{tabular}


Analisis Potensi Energi Terbarukan (Bawan, E. K., Palintin, A. D., \& Patandianan, E. A.)

Selatan terdiri dari 6 distrik dan 57 desa dengan laus wilayah $2.812,44 \mathrm{~km}^{2}$. Dilihat dari komposisi jumlah desa dan kelurahan, Distrik Oransbari memiliki jumlah desa terbanyak yaitu 14 desa sedangkan distrik Tahota yang paling sedikit yaitu 4 desa. Secara rinci, demografi Kabupaten Manokwari Selatan dapat dilihat pada Tabel 1. Penduduk Kabupaten Manokwari Selatan berdasarkan hasil proyeksi penduduk tahun 2019 sebanyak 24.220 jiwa yang terdiri atas 11.970 laki-laki dan 11.013 perempuan.

Kepadatan penduduk pada tahun 2018 mencapai $8,40 \%$ jiwa/ $/ \mathrm{Km}^{2}$. Kepadatan penduduk di empat distrik cukup beragam dengan kepadatan penduduk tertinggi terletak di Distrik Ransiki dengan kepadatan sebesar 37,28 jiwa/ $\mathrm{Km}^{2}$ dan terendah di Distrik Tahota sebesar 1,03 jiwa/ $\mathrm{Km}^{2}$ (BPS Kabupaten Manokwari, 2019)

Wilayah Kabupaten Manowkari Selatan yang berada di pegunungan dan dengan adanya sungai membuka peluang pengembangan pembangkit listrik tenaga air khususnya skala mikrohidro untuk memenuhi kebutuhan penduduk akan energi listrik. Di Manokwari Selatan terdapat enam sungai besar yang ada seperti pada Tabel 2. Akan tetapi, pemanfaatan potensinya seringsungai dibatasi oleh ketersediaan data karena terbatasnya studi dan penelitian terkait.

Tujuan dari penelitian ini adalah menganalisis potensi energi listrik di kabupaten
Manokwari Selatan di empat kampung yaitu kampung Inyuara, Sihu, Skajo, dan Susmorof.

\section{METODE}

Penelitian dilaksanakan pada bulan Juli 2019 di Kabupaten Manokwari Selatan pada tiga Distrik Dataran Isim Kampung Tahosta, Inyuara, Umousi, Duhugesa, dan Tubes; Distrik Tahota Kampung Sihu; dan Distrik Kampung Susmorof. Penentuan lokasi penelitian ini didasarkan atas pertimbangan bahwa daerah tersebut belum dialiri oleh listrik dan diduga memiliki potensi sungai yang baik untuk PLTMH serta masukan dari pemerintah daerah dan PT. PLN Cabang Manokwari.

Survei geologi dilakukan dengan pendekatan geologi regional Lembar Ransiki (Pieters, 1990) dan Lembar Steenkol (Robinson, 1990). Untuk analisis hidrologi dan kemiringan lereng dilakukan dengan menggunakan citra satelit, Digital Elevation Model (DEM), Peta Rupa Bumi Indonesia (RBI), dan aplikasi Sistem Informasi Geografis (SIG) serta pengukuran di lapangan untuk penentuan debit lapangan yang nantinya akan menjadi perbandingan dengan hasil perhitungan debit andalan. Kondisi hidrologi yang menjadi kajian meliputi potensi debit dan curah hujan dimana termasuk di dalamnya terkait perubahan iklim (Direktorat Jenderal Listrik dan Pemanfaatan Energi, 2009). 
Perhitungan debit air pada DAS menggunakan metode FJ. Mock memerlukan data klimatologi dari Badan Meteorologi dan Geofisika (BMKG). Data evapotranspirasi potensial dihitung dengan menggunakan metode Pennman Modifikasi (Pratama, 2016; Nugroho dkk., 2017).

Hasil perhitungan debit setiap bulan selama beberapa tahun kemudian disusun dan ditentukan tingkat keandalannya yang dipilih berdasarkan probabilitas kejadian mengikuti rumus Weibull dan membentuk kurva yang dinamakan Flow Duration Curve (FDC).

$$
P=\frac{i}{n+1} \times 100 \%
$$

Dengan $i$ adalah nomor urut debit dengan urutan kejadian dari besar ke kecil, $n$ adalah jumlah data, dan $P$ adalah probabilitas terjadinya kumpulan nilai yang diharapkan selama periode pengamatan (\%). Dalam kajian ini dipilih debit andalan dengan persentase 80\%-96\% (Kusumastuti dkk., 2016).

Untuk mendapatkan daya hidrolik $\left(P_{h}\right)$ yang merupakan potensi sumber daya energi air pada suatu wilayah, didapatkan dengan persamaan (2). Potensi hidrolik adalah potensi energi yang ditimbulkan oleh tekanan air akibat gravitasi bumi. Potensi energi mikrohidro yang tersedia di alam adalah merupakan potensi hidrolik dalam bentuk energi potensial. Besarnya potensi hidrolik dipengaruhi oleh besarnya debit dan ketinggian/kemiringan suatu sungai atau head (Sogen, 2017).

$$
P_{h}=Q x H x g
$$

Potensi daya listrik (PLTMH) yang dapat dibangkitkan berdasarkan hasil perhitungan potensi hidrolik. Energi dalam bentuk potensial hidrolik tidak semuanya dikonversi menjadi tenaga listrik. Pada saat konversi dari energi potensial menjadi energi listrik sebagian energi akan hilang dalam bentuk losses. Selain hal tersebut, juga sangat dipengaruhi oleh besarnya efisiensi komponen seperti turbin dan generator yang digunakan pakai rumus (Nugroho dkk., 2017, p. 169). Nilai efisiensi yang digunakan

\section{Gambar 1 \\ Diagram Alir Perhitungan FJ. Mock

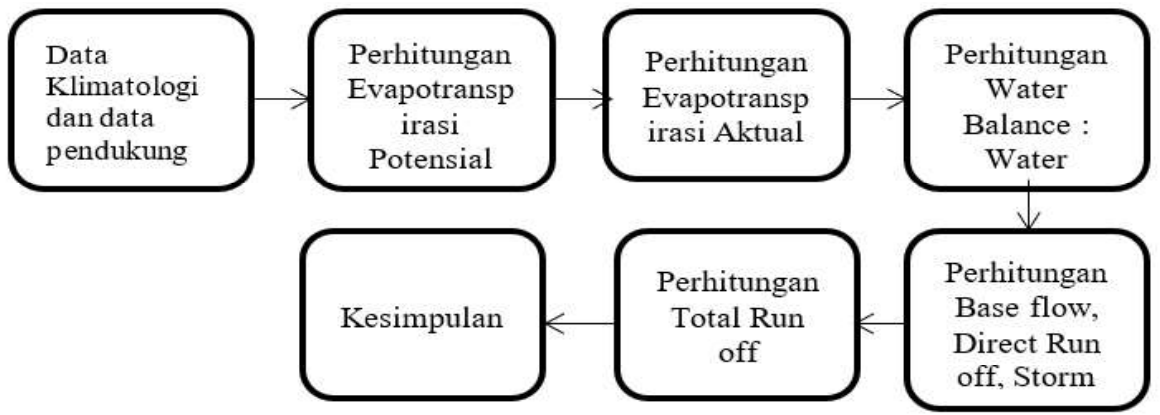


Analisis Potensi Energi Terbarukan (Bawan, E. K., Palintin, A. D., \& Patandianan, E. A.)

adalah 0,68. Kapasitas daya pembangkit $(P e)$ disajikan pada persamaan (3).

$$
P_{e}=\eta_{T} x \eta_{G} x \eta_{M} x P_{h}
$$

Dengan $P_{h}$ adalah potensi hidrolik $(\mathrm{kW}), P_{e}$ adalah potensi daya listrk $(\mathrm{kW})$, $\boldsymbol{\eta}_{T}$ adalah efisiensi turbin, $\boldsymbol{\eta}_{G}$ adalah efisiensi generator, $\boldsymbol{\eta}_{M}$ adalah efisiensi transmisi mekanik, $g$ adalah gaya gravitasi $\left(9,8 \mathrm{~m} / \mathrm{dt}^{2}\right)$, $Q$ adalah debit andalan $\left(\mathrm{m}^{3} / \mathrm{dt}\right)$ dan $H$ adalah tinggi efektif (m).

\section{HASILDAN PEMBAHASAN}

Daerah survei potensi energi terbarukan di Kabupaten Manokwari Selatan terdiri atas berbagai variasi litologi pada tiap formasi batuan. Pertama, Kampung Sosmorof terletak pada Formasi Kemum
(SDk) yang merupakan batuan sedimen malih tingkat rendah berupa batusabak, serpih, argilit, batulanau berlapis batupasir, dan konglomerat. Batuan malihan tingkat sedang - tinggi berupa batusabak, filit, slate, batupasir malih, kuarsit, konglomerat malih, sekis, gneis, batugamping malih, basal dan andesit malih. Sedangkan pada Sungai Sosmorof yang lokasi pengukuran berada pada Formasi Aluvium (Qa) merupakan pasir, kerikil, gambut dan bahan tumbuhan, juga melewati Formasi Kemum (SDk) dan Formasi Granit Anggi (Ra) berupa litologi Granit. Kedua, Distrik Dataran Isim terletak pada Formasi Aluvium (Qa) berupa bahan rombakan pasir, kerikil, gambut, dan bahan tumbuhan. Ketiga, Kampung Sihu terletak

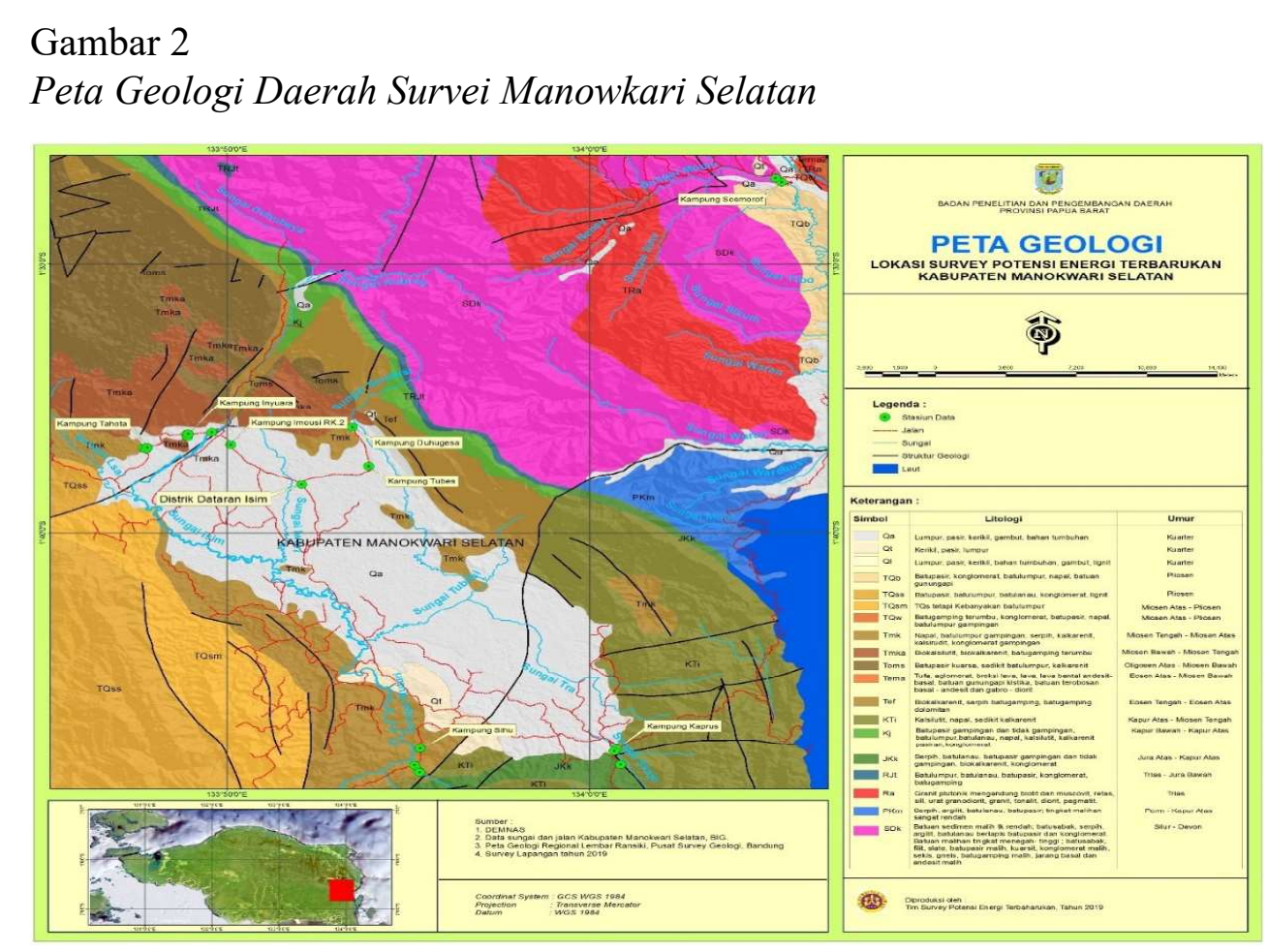




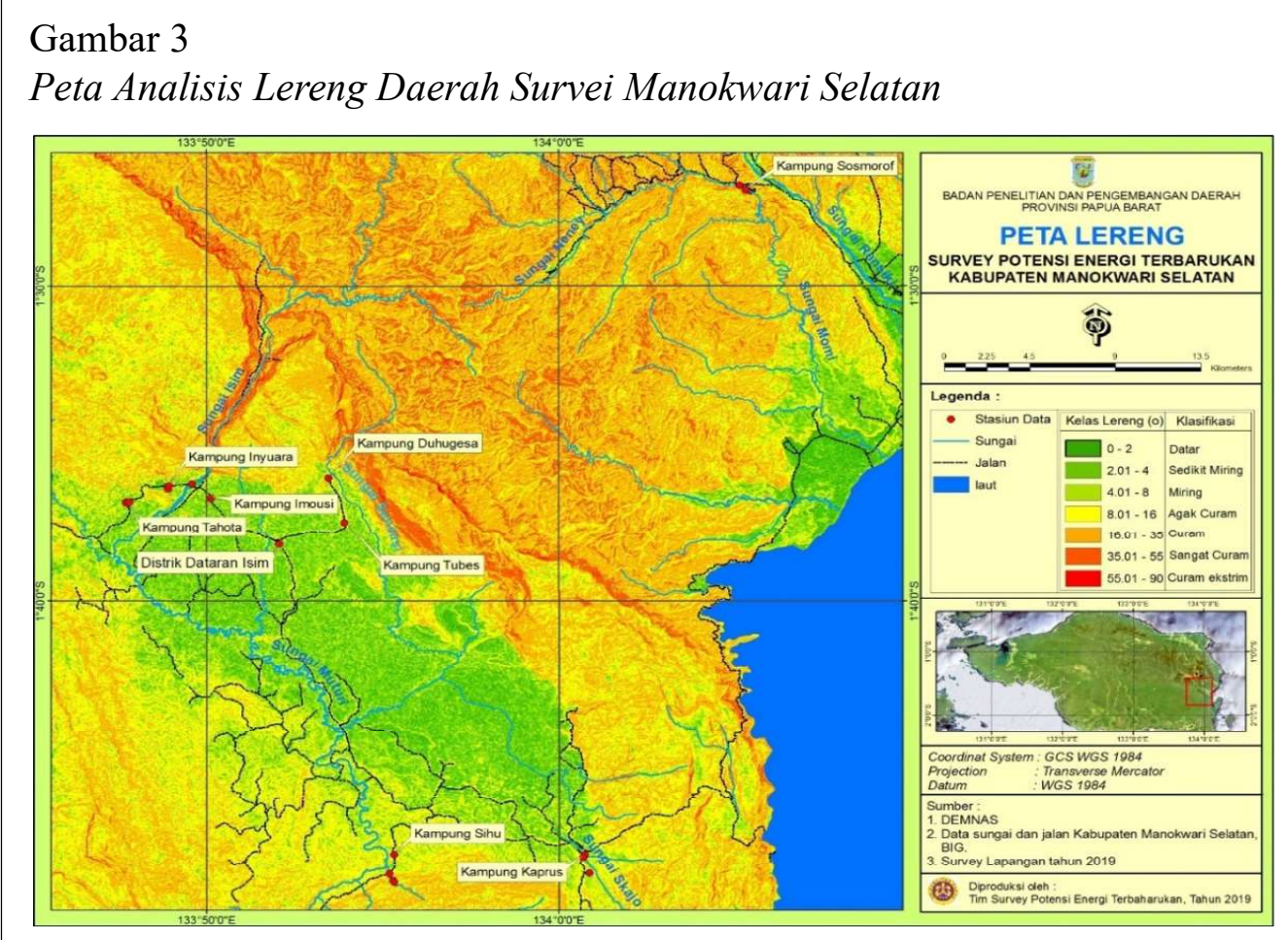

pada Formasi Klasafet (Tmk) dengan litologi Napal, batu lumpur gampingan, serpih, kalkarenit, kalsirudit, dan konglomerat gampingan. Sungai Bengko yang terletak di Kampung Sihu juga melewati Formasi Kelompok klembangan (JKk) berupa litologi serpih, batulanau, batupasir gampingan, dan tidak gampingan, biokalkarenit dan konglomerat serta Formasi Batugamping Imskin (KTi) berupa litologi Kalsilutit, napal, dan kalkarenit. Keempat, Kampung Kaprus terdapat Sungai Skajo terletak pada Formasi Kelompok Kembelangan (JKk) dan Formasi Batugamping Imskin (KTi).

Morfologi Daerah Distrik Dataran Isim yang terdiri atas Kampung Tahosta, Inyuara, Umousi, Duhugesa, dan Tubes masuk dalam satuan dataran dan daerah rata aluvium dan litoral dengan kemiringan lereng dalam klasifikasi Van Zuidam Tahun 1985 merupakan daerah dengan morfologi yang rata sampai sedikit miring dengan kemiringan lereng 2-4 ${ }^{\circ}$. Kampung Sihu dan Kampung Kaprus masuk dalam satuan fisiografis Pegunungan Imskin-Kaputih dengan morfologi agak curam sampai curam dengan kemiringan lereng 8-35 . Sedangkan Kampung Sosmorof masuk dalam fisiografis Pegunungan Bagian tengah Kepala Burung dengan morfologi curam sampai sangat curam dengan kemiringan lereng $16-55^{\circ}$.

Di wilayah Kabupaten Manokwari Selatan terdapat 6 buah sungai yang cukup panjang. Sungai Momi merupakan sungai 
Analisis Potensi Energi Terbarukan (Bawan, E. K., Palintin, A. D., \& Patandianan, E. A.)

yang terpanjang, yaitu $34 \mathrm{~km}$ sebagaimana terlihat pada Tabel 2.

Sungai-sungai di Kabupaten Manokwari Selatan umumnya membentuk pola aliran dendritik, serta tipe genetik konsekuen dan obsekuen. Sebagian besar anak sungai yang mengalir ke sungai utama berjenis sungai permanen atau mengalir sepanjang tahun yang menyuplai air ke sungai utama.

Adapun sungai-sungai yang disurvei di Kabupaten Manokwari Selatan yang berpotensi untuk PLTMH adalah Sungai Bengko dengan debit pengukuran sebesar 114,6 L/s dengan luas Daerah Aliran Sungai $4,17 \mathrm{Km}^{2}$, serta Sungai Sosmorof dengan debit 4917,6 L/s dengan luas Daerah Aliran Sungai $123,88 \mathrm{Km}^{2}$.

Pengukuran debit air di Kabupaten Manokwari Selatan dilakukan di empat sungai, yaitu Sungai Bahames di Kampung Inyuara, Sungai Skajo di Kampung Kaprus, Sungai Bengko di Kampung Sihu dan Sungai Susmorof di Kampung Susmorof. Dokumentasi pengukuran dan hasil debit pengukuran lapangan ditunjukkan pada Gambar 4 dan Tabel 3.

Analisis debit andalan dilakukan dengan model F. J Mock yang memerlukan data suhu, kelembaban, curah hujan, penyinaran matahari, dan kecepatan angin.

Tabel 2

\begin{tabular}{clccl}
\multicolumn{2}{c}{ Nama } & Sungai di Kabupaten Manokwari Selatan & \\
\hline No & Nama Sungai & Panjang $(\mathrm{Km})$ & $\mathrm{Q}\left(\mathrm{m}^{3} / \mathrm{s}\right)$ & Lokasi/Distrik \\
\hline 1 & Momi & 34 & NA & Ransiki \\
2 & Ransiki & 32 & 76,153 & Ransiki \\
3 & Waren & 19 & NA & Ransiki \\
4 & Masabui & 18 & 18,958 & Oransbari \\
5 & Warbiadi & 16 & NA & Oransbari \\
6 & Muari & 10 & NA & Oransbari \\
\hline
\end{tabular}

\section{Gambar 4}

Pengukuran Debit Air di Sungai Susmorof (kiri) dan Sungai Bengko (kanan)
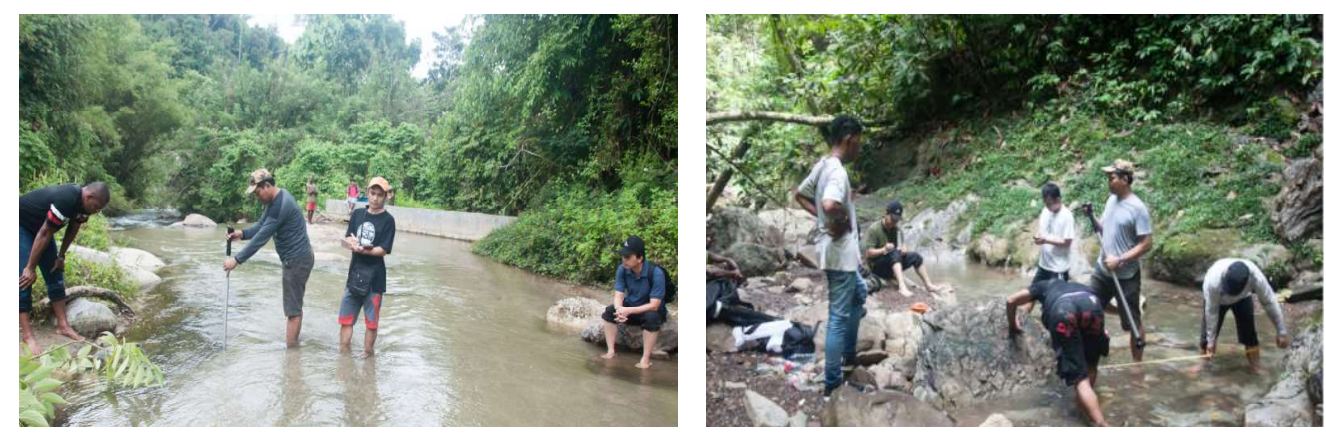
Jurnal Penelitian Saintek, Vol. 26, Nomor 1, 2021

Tabel 3

Hasil Pengukuran Debit Beberapa Lokasi di Kabupaten Manokwari Selatan

\begin{tabular}{llccccc}
\hline \multirow{2}{*}{ No } & \multirow{2}{*}{ Sungai/Kampung } & Titik & \multicolumn{2}{c}{ Lokasi } & Debit & Potensi \\
& & Data & Lintang & Bujur & $(\mathrm{m} 3 / \mathrm{det})$ & Head $(\mathrm{m})$ \\
\hline 1 & Baharmes/ & Titik 1 & -1.607333 & 133.815139 & 0.0052 & 2 \\
& Inyuara & Titik 2 & -1.607333 & 133.815222 & & \\
2 & Bengko/Sihu & Titik 1 & -1.813759 & 133.921307 & 0.1146 & 70 \\
& & Titik 2 & -1.810722 & 133.919694 & & \\
\multirow{2}{*}{3} & Sosmorof/ & Titik 1 & -1.446833 & 134.08575 & 4.9176 & 10 \\
& Sosmorof & Titik 2 & -1.449388 & 134.0885 & & \\
4 & Skajo/Kaprus & Titik 1 & -1.805437 & 134.013617 & 0,001 & 13 \\
& & Titik 2 & -1.80062 & 134.012234 & & \\
\hline
\end{tabular}

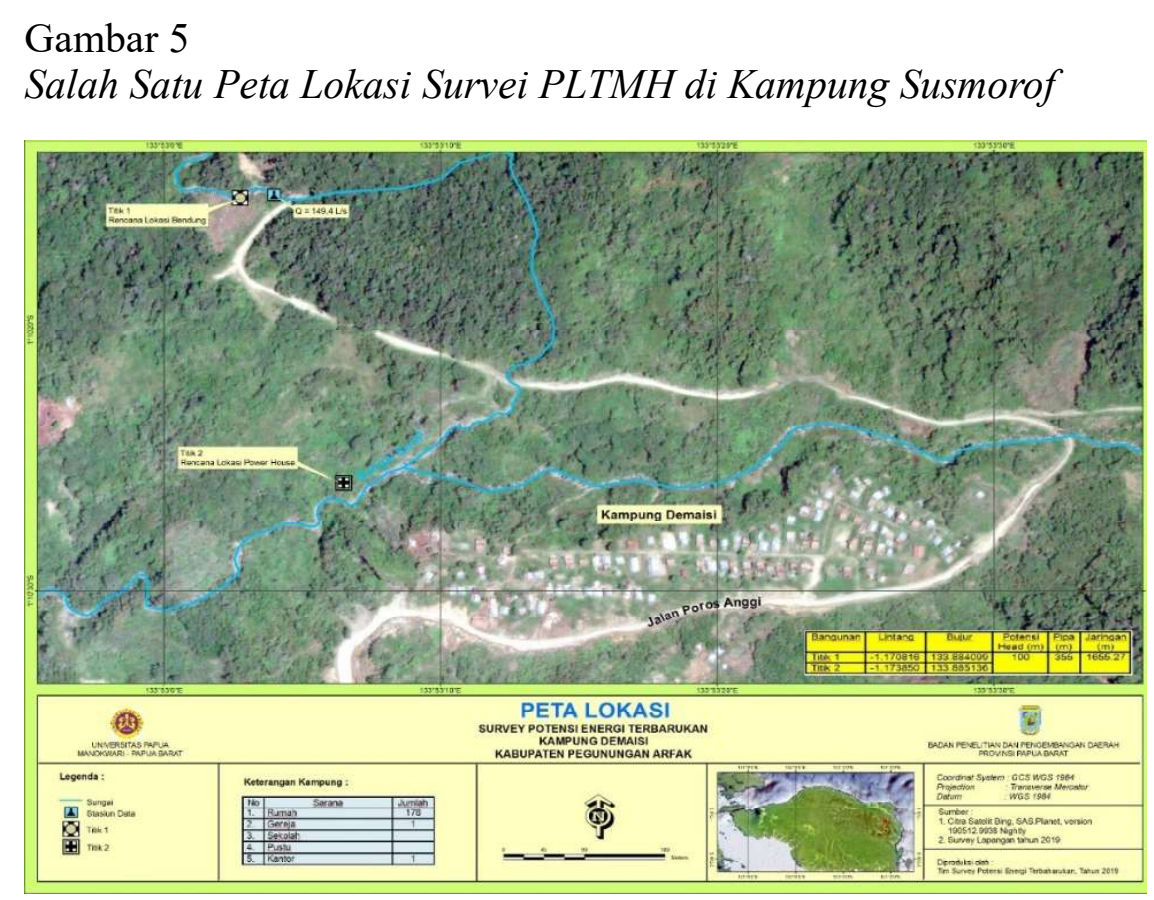

Model ini dihasilkan dari penelitian empiris dengan memasukkan data hujan bulanan, evapotranspirasi potensial bulanan, dan parameter-parameter fisik lainnya yang sifatnyajuga bulanan sehingga menghasil-kan debit aliran simulasi bulanan. Untuk analisis debit andalan sungai-sungai di Kabupaten
Manokwari Selatan menggunakan data selama empat tahun dari tahun 2015-2018.

Penentuan head bersih dipengaruhi oleh jarak dari rencana bendung ke rumah pembangkit (power house). Untuk sungai Bengkok diperoleh hasil perhitungan head bersih sebesar 69,74 m. Dengan head bersih 
Analisis Potensi Energi Terbarukan (Bawan, E. K., Palintin, A. D., \& Patandianan, E. A.)

Gambar 6
Kurva Probabilitas Debit Sungai Bengko

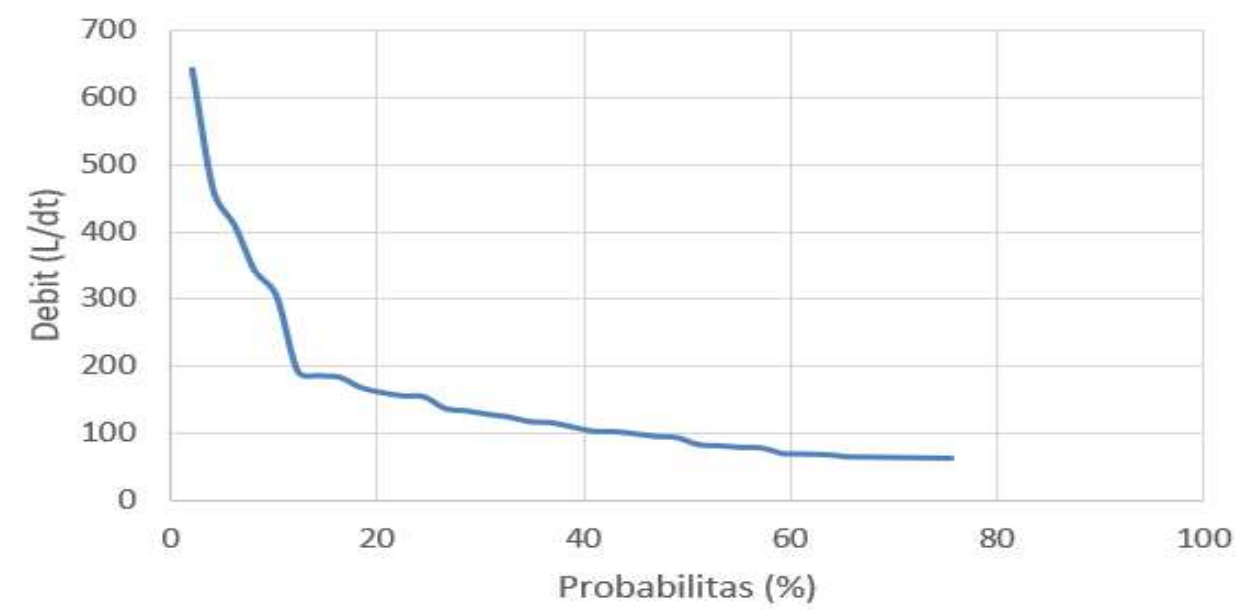

Keterangan: Debit andalan: 65 L/dt; Head kotor (gross head): 70 m; Gravitasi bumi: $9,8 \mathrm{~m} / \mathrm{dt}^{2}$

Tabel 4

Perhitungan Potensi PLTMH Di Kabupaten Manokwari Selatan

\begin{tabular}{clcccccc}
\hline No & Sungai/Kampung & $\begin{array}{c}\text { Debit } \\
\text { Pengukuran } \\
(\mathrm{L} / \mathrm{dt})\end{array}$ & $\begin{array}{c}\text { Debit } \\
\text { Andalan } \\
(\mathrm{L} / \mathrm{dt})\end{array}$ & $\begin{array}{c}\text { Potensi } \\
\text { Head } \\
(\mathrm{m})\end{array}$ & $\begin{array}{c}\text { Net } \\
\text { Head } \\
(\mathrm{m})\end{array}$ & $\begin{array}{c}\text { Potensi } \\
\text { Hidrolik } \\
(\mathrm{kW})\end{array}$ & $\begin{array}{c}\text { Daya } \\
\text { PLTMH } \\
(\mathrm{kW})\end{array}$ \\
\hline 1 & 114,6 & 65 & 70 & 69,74 & 44,4 & 30,4 \\
2 & $\begin{array}{l}\text { Bengko/Sihu } \\
\text { Sosmorof }(\text { Untuk } \\
\text { redesign PLTMH }\end{array}$ & 4917,6 & 500 & 10 & 6,24 & 30,6 & 21 \\
$\begin{array}{l}\text { Existing) } \\
\text { Sosmorof (Potensi }\end{array}$ & 4917,6 & 1500 & 10 & 7,29 & 107,1 & 73,4 \\
\hline
\end{tabular}

sebesar itu diperoleh potensi hidrolik $\left(P_{h}\right)$ sebesar 44,4kW.

Potensi daya listrik yang dapat dibangkitkan berdasarkan perhitungan potensi hidrolik adalah sebagai berikut.

$\begin{array}{lll}\text { Efisiensi turbin } & : & 0,76 \\ \text { Efisiensi generator } & : & 0,92 \\ \text { Efisiensi mekanis } & : & 0,98\end{array}$

Kapasitas daya pembangkit $\left(P_{e}\right): 30,4 \mathrm{~kW}$

\section{SIMPULAN}

Berdasarkan hasil dan pembahasan dapat disimpulkan bahwa debit andalan pada sungai Susmorof mencapai $1500 \mathrm{~L} /$ dt masing-masing untuk kepentingan pengembangan sistem; total potensi PLTMH di dua lokasi yang dikaji adalah sebesar 30,4 $\mathrm{kW}$ di sungai Bengko kampung Sihu dan $73,4 \mathrm{~kW}$ untuk pengembangan PLTMH di 
Kampung Susmorof; dan PLTMH Susmorof penting untuk ditindaklanjuti pada tahapan studi kelayakan dan penyusunan perencanaan detail desain.

\section{DAFTAR PUSTAKA}

BPS Kabupaten Manokwari. (2019). Kabupaten Pegunungan Arfak dalam angka 2019. BPS Kabupaten Manokwari.

Direktorat Jenderal Listrik dan Pemanfaatan Energi. (2009). Buku 2A pedoman studi kelayakan hidrologi. Departemen Energi dan Sumber Daya Mineral.

Ellabban, O., Abu-Rub, H., \& Blaabjerg, F. (2014). Renewable energy resources: Current status, future prospects and their enabling technology. Renewable and Sustainable Energy Reviews, 39, 748-764.

Kementerian ESDM. (2016). 2.519 desa belum teraliri listrik. Kementerian ESDM.

Galvez, B. M. (2015). Investing in renewable energy generation and power transmission in Eastern Indonesia. Asian Development Bank.

Kusumastuti, D. I., Winarno, D. J., Humaidi, Falah, M. N., \& Robiyanto. (2016). Estimasi potensi PLTMH dengan metode regionalisasi pada ungauged catchments di Kecamatan Suoh. Jurnal Teknik Sipil, 63-74.

Tan, Y., Meegahapola, L., \& Muttaqi, K. M. (2014). A review of technical challenges in planning and operation of remote area power supply systems. Renewable and Sustainable Energy Reviews, 38, 876889.

Nugroho, D., Suprajitno, A., \& Gunawan. (2017). Desain pembangkit listrik tenaga mikrohidro di air terjun Kedung Kayang. Jurnal Rekayasa Elektrika, 13(3), 161171.

Oktaviani, K. (2016). Prakiraan penyediaan dan pemanfaatan energi skenario optimalisasi EBT Daerah. Pusat Data dan Teknologi Informasi Kementerian ESDM.

Palintin, A. D. (2020). Potensi pembangkit listrik tenaga mikrohidro di Kabupaten Pegunungan Arfak. Igya Ser Hanjop, 11-24.

Pieters, P. E. (1990). Geologi lembar Ransiki, Irian Jaya. Departemen Pertambangan dan Energi, Direktorat Jenderal Geologi dan Sumberdaya Mineral, Pusat Penelitian dan Pengembangan Geologi.

Pratama, F. S. (2016). Potensi pembangkit listrik tenaga mikrohidro dan pemanfaatannya untuk masyarakat di Daerah Aliran Sungai Cikurai (Disertasi doktor tidak diterbitkan). Universitas Pendidikan Indonesia, Bandung.

Pasalli, Y. R., \& Rehiara,A. B. (2014). Design planning of micro-hydro power plant in Hink River. Procedia Environmental Sciences, 20, 55-63.

Reinders, K. K. (2020). The electricity grid in Indonesia. Springer.

Robinson, G. P. (1990). Geologi lembar Steenkool, Irian Jaya. Pusat Penelitian dan Pengembangan Geologi.

Sogen, M. D. (2017). Studi perencanaan pembangunan PLTMH di Kampung Sasnek Distrik Sawiat Kabupaten Sorong Selatan Provinsi Papua Barat. Electro Luceat.

Tobi, M. D., \& Van Harling, V. N. (2017). Studi perencanaan pembangunan PLTMH di Kampung Sasnek Distrik Sawiat Kabupaten Sorong Selatan Provinsi Papua Barat. Electro Luceat, 3(1), 32-43. 